\title{
INHERITANCE WITH DIFFERENT RELIGIONS IN COUNTER LEGAL DRAFT OF ISLAMIC LAW COMPILATION: LEGAL EPISTEMOLOGICAL ANALYSIS
}

\author{
Ahmad Irfan \\ Lecturer at State Institute of Islamic Studies (IAIN) Bone \\ Email: irfanxnahdliyyin@gmail.com
}

\begin{abstract}
Islamic inheritance in Counter Legal Draft of Islamic Law Compilation (CLD-KHI) is still an unfinished discussion. Legal reconstruction and contextualization in the modern era have made CLDK interesting to be raised to the surface. Reformulation of Islamic law in various legal constructs seems to be reviewed. This can be seen in several courts, even in jurisprudence that has provided opportunities for an inheritance to non-Muslims. This study is classified as a literature study, which focuses on legal epistemology based on Islamic inheritance in CLDK. This study found that religious differences as a barrier to the inheritance process have maqashid al-shariah in Islam and the value of justice and humanity. Correspondingly, critical and in-depth elaboration of the study of the epistemology of the inheritance law of different religions needs to continue to be developed towards a more comprehensive and constructive paradigm and renewal. Thus, the direction and purpose of Islamic law do not release the essential values that have become the spirit of Islam. This study implies that in the formation of human souls. They are able to portray themselves ideally as the caliph of Allah, on the face of the earth, which always has a sensitivity to every gap and structural and cultural injustice and to realize Islam as rahmatan li al-alamin (mercy to the worlds). That needs to be realized in the nine priorities (nawacita) of inheritance law in the establishment of inheritance law in Indonesia.
\end{abstract}

Kewarisan Islam dalam Counter Legal Draft Kompilasi Hukum Islam (CLDKHI) masih belum final untuk dibahas. Rekonstruksi dan kontekstualisasi hukum di era modern menjadikan CLDK menarik untuk diangkat kepermukaan. Reformulasi hukum Islam diberbagai konstruk hukum tampaknya perlu dikaji kembali. Hal itu terlihat dibeberapa peradilan, bakan dalam yurisprudensi telah memberikan peluang waris terhadap non-muslim. Kajian ini tergolong kajian studi pustaka, yang terfokus pada epistemologi hukum dalam basis kewarisan Islam dalam CLDK. Temuan kajian ini bahwa perbedaan agama sebagai penghalang proses waris mewarisi, telah menciderai maqashid al-syari'ah dalam Islam serta nilai 
keadilan dan kemanusiaan. Sejalan dengan itu, elaborasi kritis dan mendalam terhadap kajian epistemologi hukum kewarisan beda agama perlu terus dikembangkan ke arah paradigma dan pembaharuan yang lebih komprehensif dan konstruktif. Sehingga arah dan tujuan Hukum Islam tidak melepaskan nilai-nilai esensial yang telah menjadi spirit keislaman. Implikasi kajian ini bahwa dalam pembentukan jiwa-jiwa manusia yang mampu memerankan dirinya secara ideal sebagai khalifah Allah Swt., di muka bumi yang senantiasa memiliki sensitifitas terhadap setiap kesenjangan dan ketidakadilan struktural maupun kultural serta mewujudkan Islam sebagai rahmatan li al'-alamin. Hal itu perlu diwujudkan dalam nawacita hukum kewarisan dalam pembentukan hukum waris di Indonesia.

Keywords: Legal Epistemology, Inheritance with different religion, CLD-KHI

\section{INTRODUCTION}

Islam examines various problems in the structure of human life, one of which is the problem of family law. The matter continues to be studied by Islamic scholars in classical as well as in contemporary times, resulting in a change of law following the results of their studies in each era. Islam can accept the need for significant changes through alterations in religious legal norms. ${ }^{1}$

The breakthrough in forming the Counter Legal Draft of Islamic Law Compilation is one of the efforts made by the drafting team to realize a Constitution on family law in the field of marriage, inheritance and responsiveness that is responsive, accommodating and comprehensive. Counter Legal Draft of Islamic Law Compilation as an antithesis to the Islamic Law Compilation in Presidential Instruction No. 1 of 1991 is expected to be able to fill the deficiencies in Islamic Law. However, the Counter Legal Draft of Islamic Law Compilation needs to be reviewed and criticized so that its shortcomings can be fixed.

One thing that is very interesting to study in the Counter Legal Draft of Islamic Law Compilation is about the concept of inheritance law. This is one of the problems of Islamic inheritance law in Indonesia and one of the controversial issues that led to the rejection of the Counter Legal Draft of Islamic Law Compilation in various circles. That is because some of the articles in the Counter Legal Draft of Islamic Law Compilation are diametrically different from the concept of inheritance law that is believed, understood, and applies in Indonesian Islamic society. One of the reasons for the refusal is because in the Counter Legal Draft of Islamic Law Compilation, there is an Article that reads "Difference in

\footnotetext{
${ }^{1}$ Abdurrahman Wahid, Hukum Islam di Indonesia (2 ${ }^{\text {nd }}$ Ed.; Bandung: Remaja Rosdakarya,
} 1994), p. 1. 
Religion is not an Obstacle to the Inheritance Process". ${ }^{2}$

Hadith as an explanation of the Holy Qur'an, ${ }^{3}$ firmly explains the obstacles to inheritance, partly because of slavery, murder and religious differences. ${ }^{4}$ In the classical jurisprudence of fiqh mentioned, one of the causes of the severance of a person's inheritance is when the person is in a non-muslim condition (infidel) and or in a situation of apostasy. The difference in religion between the inheritor and the heir is one of the reasons someone's inheritance is severed. As mentioned in the hadith narrated by several mukharij from Usamah bin Zaid, which reads:

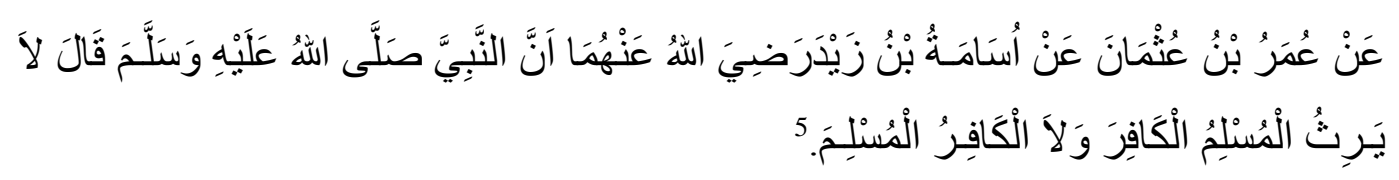

The meaning:

Narrated from Umar bin Usman, from Usamah bin Zaid said the Messenger of Allah (pbuh), the Muslims do not inherit the infidels and the infidels do not inherit the Muslims.

The material of the hadith about the inheritance with different religions, in substance from the text, is related to the status of the Prophet as a messenger, judge or community leader. If the first category is taken, then the text of the hadith becomes universal in nature, if the second category means related to the ijtihadi aspect which with all its aspects are related to certain situations and conditions. Whereas if the third category becomes the interpretation, then of course it is the same as the second aspect, which is part of ijtihadi which at any time the text can be changed at any time. Herein lies the problem of the hadith, whether it must be understood textually or contextually. Then it becomes intriguing to review the article in the Counter Legal Draft of Islamic Law Compilation about the inheritance with different religions. It is interesting because there is quite a controversy in the text of the article that reads 'Different Religion is not an Obstacle to the Inheritance Process'. The editorial in that article will be reviewed from the epistemology of Islamic law based on the arguments of the Holy Qur'an

189.

${ }^{2}$ M. Syafi'ie, Hak Non Muslim terhadap Harta Waris (t.c; Yogyakarta: Al- Mawarid, 2011), p.

${ }^{3}$ The Holy Quran and Hadith are the main sources in Islam. The two complement each other, especially if there is no explanation in the first source. See Abdul Wahab Khallaf, Science of Usul Fiqh, translated by Noer Iskandar al-Barsany and Moh. Tolchah Mansoer, Kaidah- Kaidah Hukum Islam (4 ${ }^{\text {th }}$ Ed.; Jakarta: Raja Grafndo Persada, 1994), p. 53-56

${ }^{4}$ Wahabah al-Zuhaili, Al-Fiqh al-Islami wa Adillatuhu, Juz X (4 ${ }^{\text {th }}$ Ed.; Damsyik: Dar al-Fikr, 1997), p. 7710.

${ }^{5}$ Muhammad bin Ismail al-Bukhari, Sahih al-Bukhari, Juz IV (Indonesia: Maktabah Dahlan, t.th), p. 2706. 
and the traditions and studies of contemporary fiqh concerning the inheritance with different religions.

\section{DISCUSSION}

\section{A. Conception about Non-Muslims}

Conception about non-muslims is always associated with pagan terms. Meanwhile, when the Holy Quran is read, then many words are found kafir or kufr. The Holy Quran places infidels as the center of all evil and as opposed to the word faith which is the source of all goodness. Because the position of the pagan term is quite central in The Holy Quran, so thoughts about pagan terminology are still growing. In fact, it is important to be studied systematically and deeply to obtain a comprehensive and comprehensive understanding. ${ }^{6}$

The term kufr is mentioned 525 times in The Holy Quran; ${ }^{7}$ the term kufr does not only form a pivot circle containing all other negative properties. But it also occupies a very important place in the entire system of the Holy Quran's ethics, so that understanding of how the word kufr is semantically structured is almost as a prerequisite for a proper assessment of most positive traits. ${ }^{8}$ Even the birth of theology started from a debate about the pagan connotation in an applicative manner, ${ }^{9}$ so the role played by the concept of kufr greatly influences all aspects of human behavior or behavior.

The concept of faith or belief as the highest religious ethical value in Islam, is very effectively analyzed through the understanding of kufr or from the negative side. In terminology, $k u f r$ has various meanings including covering, erasing, contextually meaning farmers. ${ }^{10}$ In the context of The Holy Quran, the form of the past verb, the word kufr refers to the infidel community of Mecca, unless there are specific signs and indications. If related to pre-Islamic literature, the term kufr refers more to the connotation of being ungrateful or ungrateful, so that the word pagan according to its origin is the opposite of the word syakir, which is a person who is

\footnotetext{
${ }^{6}$ Harifuddin Cawidu, Konsep Kufr dalam Alquran; Suatu Kajian Teologi dengan Pendekatan Tafsir Tematis (1 $1^{\text {st }}$ Ed.; Jakarta: Bulan Bintang, 1991), p. 18

${ }^{7}$ Harifuddin Cawidu, Konsep Kufr dalam Alquran, p. 30.

${ }^{8}$ Mustafa Umar, Konsep Kufur dalam Alquran dan Proyeksinya Terhadap Teks Hadis (t.c; Makassar: Al- Risalah, 2012), p. 48

${ }^{9}$ The basic opposition to a person committing a big sin whether as a believer or entered in the infidel category into the initial debate the emergence of theological schools. The Khawarij considered them as the infidels, Asya'ariyah considered them as Fasiq believers, Murji'ah said that they are still believers, while the Mu'tazilah group took the middle position between believer and the infidel. See Mustafa Umar, Konsep Kufur dalam Alquran, p. 48.

${ }^{10}$ See the Holy Quran Surah. al-Hadid (57): 20
} 
grateful. ${ }^{11}$ One of the fundamental beliefs is to give thanks as a consequence of God's generous and loving nature for all creation. Thus, the word pagan which means one who does not believe in God or the opposite of a believer is a secondary meaning. However, it cannot be denied that the semantic category of the word kufr contains important aspects of faith.

To find out the change in meaning, Izutsu tried to explain chronologically later by taking a few cases from quotations from the Holy Quran. The basic meaning of the kafara root is to cover up or to deliberately ignore the pleasure that has been obtained then to not be grateful. In this context, an infidel means a person who denies the grace of God. An ungrateful attitude related to God's grace and goodness is expressed in the most radical expression of disbelieving God, His prophets, and revelations.

Kufr is more often associated with opponents of faith, so kufr increasingly loses its original semantic core that is not ungrateful, and increasingly leads to the meaning of unbelief. The last understanding is most widely used. If the understanding of God's signs is a gift that requires humans to give thanks, then the denial of that is categorized as ungrateful. While the signs of God in the sense of manifestation of His power that requires humans to believe it. Then the denial of that is categorized as unbelief. As in the case of the denial of the disclosure of natural phenomena, the day of the resurrection, the case which gives clarity the opposite of the semantic words of kufr and faith is the denial of God. At its peak Kufr can be categorized as the opposite of taqwa which is a central aspect of the Islamic view in general. ${ }^{12}$

Implicitly Abdullah Ahmed An-Na'im and Masdar Farid Mas'udi said that the conception of infidels (kufr) is currently irrelevant to be applied if it contains discriminatory effects, injustice and harming human rights. The conception of infidels or apostates in Islamic jurisprudence mentioned as the cause of obstruction of the inheritance must be revoked because the barrier in the name of infidel or apostate clearly discriminates against heirs of different religions. Infidels in their language are not like the terminology of classical scholars who are trapped in unfair terminology. ${ }^{13}$

Likewise, the opinion of Asgar Ali Engeiner, who said that infidels are not always and are not identical with non-muslims. But the so-called infidels are those who hide the truth of whoever the person is or the community. Asgar also said that those who are infidels are people who do not struggle to uphold justice, oppose

\footnotetext{
${ }^{11}$ Mustafa Umar, Konsep Kufur dalam Alquran, p. 49.

${ }^{12}$ Mustafa Umar, Konsep Kufur dalam Alquran, p. 49.

${ }^{13}$ M. Syafi'ie, Hak Non Muslim terhadap Harta Waris, p. 181.
} 
tyranny and oppression even though he believes in God. Including infidels are people who accumulate wealth, do and allow tyranny. ${ }^{14}$ The pagan concept in Ali Asgar Engineer's thinking is not merely speculative transcendental but also social and reflective in contemporary humanity.

\section{B. Position of the Hadith about the Inheritance with different religions}

There are several hadith texts which form the basis of law on the inheritance with different religions. One of them is narrated by Usamah bin Zaid. This hadith becomes the main basis for inheritance with different religions, the text of the hadith reads:

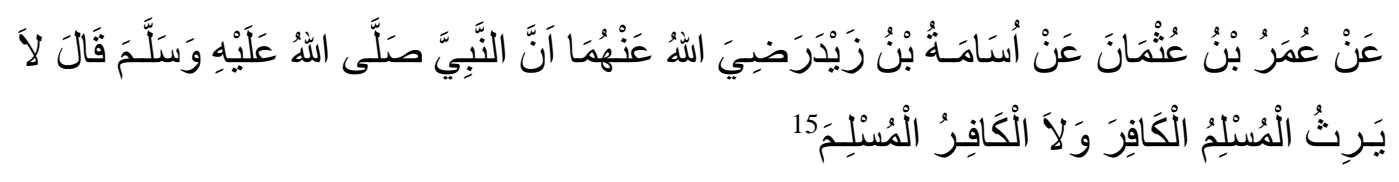

The meaning:

Narrated from Umar bin Usman, from Usamah bin Zaid said the Messenger of Allah (pbuh), the Muslims do not inherit the infidels and the infidels do not inherit the Muslims.

The sanad and matan of the hadith, the narrators of the hadith narrated form Usamah, meet the requirements of the validity of the hadith sanad, so it can be concluded as authentic sanad. The status of tsiqah includes the personal and intellectual capacity of the narrator, while in terms of the connection of sanad (almuttashil al-sanad), there is a connection between the students based on the relationship of the student teacher and the symbol used in the narration. Most of them use the al-sima' method. The critics of the hadith, especially the al-mutasaddid group, most of them assess the narrators in the tsiqah level. In quantity, the tradition of this tradition is included in the category of hadith. The status of this hadith is in the category of garib al-hadith, that is, his sanad has been alone since narrator I - IV, becoming famous after narrator IV or starting narrator $V$. Thus, the sanad and position of this hadith is valid. ${ }^{16}$

The main theme of the hadith Usamah bin Zaid discussed the issue of inheritance with the core of the discussion about religious differences as a barrier to inheritance. The context of asbab al-wurud hadith relates to the story of the Prophet Muhammad (pbuh) and his companions who performed the wada' hajj. At that time, there was Ali bin Abi Talib whose parents were still kufr in Mecca. Abu Talib and his two sons Uqail and Talib did not follow in the footsteps of Ja'far and Ali

\footnotetext{
${ }^{14}$ M. Syafi'ie, Hak Non Muslim terhadap Harta Waris, p. 181.

${ }^{15}$ Muhammad bin Ismail al-Bukhari, Sahih al-Bukhari, Juz IV, p. 2706.

${ }^{16}$ Marwan, Hadis Tentang Kedudukan Ahli Waris Beda Agama, Karya Ilmiah, 2001, p. 74
} 
accepted the truth brought by Muhammad (pbuh). ${ }^{17}$ Therefore, the meaning of the infidel needs research to be able to eliminate the suffering of the meaning of the hadith, whether the infidel in the Hadith contain meaning in general or specifically. If the special meaning is desired, then the disbelievers in the hadith are showing pagan polytheists, whereas if it has a general meaning, then the contents of this pagan meaning include all types of disbelief.

If the desired meaning of the scholars interpret the meaning of infidels in the hadith as a Muslim dichotomy, so that the disbelievers in the tradition of the tradition are general, but the clarity of the meaning of the heathen will be clear when related to the context of the verses of The Holy Quran and other hadith texts. then the disbelievers in the hadith are denominational polytheists, whereas if they have general meaning, then the content of the meanings of these infidels includes all types of disbelief. Because the tendency of pagan pronunciation, can be interpreted with various meanings in accordance with the context. Obviously, we are not included in the context of the Hadith, because there is the ability to marry a woman expert in the book, which connects the existence of inheriting each other in accordance with the purpose of the Holy Quran surah al-Maidah (5):5.

Based on the analysis of the historical context of the existence of the text of Osama's hadith, the type of infidel referred to in the hadith is a polytheist infidel. Thus, the meaning of matan and the content of the Usamah hadith. The historical approach to the context of the hadith is closer to the meaning contained in the tradition of tradition. There is no text of the Holy Quran which prohibits the inheritance with different religions, even with the unbelievers we are allowed to have a marriage, not with the polytheists. In that case there is clearly a difference between the Jewish and Christian infidels and the polytheists. There are no other traditions that are stronger than this Hadith.

\section{Interpretation of Contemporary Scholar about the Inheritance Law of Different Religions}

The generality of The Holy Quran is takhsis by the hadith of the Prophet (pbuh), this is what applies to the inheritance with different religions. the Holy Quran Surah Announcement. al-Maidah (5):5, especially the meaning which is the theme of the conversation about the ability to marry a woman expert on the book, specifically by the Hadith of Usamah bin Zaid. ${ }^{18}$ The results of ijtihad and legal conclusions show that heirs receive an inheritance if they fulfill the conditions

\footnotetext{
${ }^{17}$ Marwan, Hadis Tentang Kedudukan Ahli Waris Beda Agama, p. 83.

${ }^{18}$ Ibnu Hajar al-Asqalani, Fath al-Bari bi Syarh Shahih al-Bukhari, Juz XII (t.c; Beirut: Dar al-Fikr, 1993), p. 50.
} 
specified in inheritance and religious differences are barriers to inheritance. This is what is meant by the Prophet's explanation, on the generality of the Islamic verse. Determination of the Prophet is what later became the sunnah and the hadith.

Related to the meaning of the traditions of Usamah bin Zaid, the scholars differed in interpreting the meaning of the hadith. Therefore, theoretical Islamic law, divides the categories of scholars in several types in understanding Islamic teachings, especially in terms of non-basic religious teachings as follows:

1. The first group believes that Muslims cannot inherit one another from infidels

Among the most well-known scholars from among the friends, tabi'in and Imams of the schools, especially the four schools of Jurisprudence that you have learned in the Sunni world. The paradigm that developed in this first thought was that Muslims could not inherit each other from infidels. This opinion has become an agreement among the scholars. ${ }^{19}$

The reason that became the basis of the scholars' argument was the publicity of Usamah bin Zaid's hadith which explicitly mentions the prohibition of inheriting mutual relationship between Muslims and infidels. In addition, the hadith narrated by Ashab al-Sunan from Abdullah bin Umar, which reads:

The meaning:

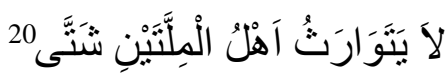

Do not inherit each other's heirs from different religions.

In syarh al-Nawawi, the scholars make the meaning of millatain with the interpretation between Islam and religions outside of Islam (infidels). Arguments based on the Holy Quran Surah al-Nisa (4): 141 also becomes the basis in determining obstruction of the inheritance with different religions. The case underlying the birth of Osama's hadith shows the historical value of the thought of religious differences preventing one from obtaining inheritance rights. In full, Ibnu Majah narrated a story that revealed that when Abu Talib died leaving four children, namely Uqail, Talib, Ja'far and Ali. Ali and Ja'far embraced Islam, while Uqail and Talib persisted in the religion of their father Abu Talib (still in disbelief). Rasulullah shared the inheritance of Abu Talib only to Uqail and Talib. ${ }^{21}$

2. The second group believes that Muslims can inherit from unbelievers, not vice versa.

The argument of the second group, as expressed by bin Hajar al-Asqalani,

\footnotetext{
${ }^{19}$ Ibnu Rusyd al- Qurtubi, Bidayat al-Mujtahid wa nihayat al-Muqtasid, Juz V ( $1^{\text {st }}$ Ed.; Beirut: Dar al-Kutub al-Ilmiyah, 1996), p. 42

${ }^{20}$ Abu Daud Sulaiman, Sunan Abu Daud, Juz III (t.c; Darul Hadis: Maktab Dahlan, 1988), p. 125

${ }^{21}$ Marwan, Hadis Tentang Kedudukan Ahli Waris Beda Agama, p. 102.
} 
including first, the argument with a hadith that was heard alone by Mu'az bin Jabal from the Messenger of Allah., which reads:

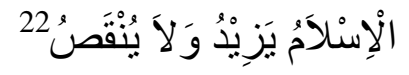

The meaning:

Islam is increasing and not decreasing.

Second, the hadith narrated by Ahmad bin Mani 'from Muaz with a strong sanad line that Muaz argued personally by giving inheritance to Muslims from infidels, not vice versa. Third, the history issued by Musaddad and Muaz that there were two people who disputed him, one Muslim and one Jewish. The father of the two men died as a Jewish, then his brother who was Jewish betrayed his Muslim brother, then Muaz gave an inheritance to his Muslim son. Fourth, bin Abi Syaibah narrated from Abdullah bin Ma'qal that I have never seen the best decision besides the decision ever taken by Mu'awiyah, that is, Muslims can inherit from an expert in the book, the book expert does not get inheritance rights from Muslims, as permissible for the Muslims to marry women who are Jewish or Christian but not vice versa.

Based on the hadith narrated by al-Daraquthni, that the height of the Islamic religion has implications for the elevation of the dignity of Muslims before non-Muslims. Inheritance is obtained from infidels, otherwise they do not get any rights. ${ }^{23}$ The correlation with the Islamic Inheritance law, Article 171, letter c, Compilation of Islamic Law (KHI), that different religion marriages do not possess the right to get inheritance if they are not of the same religion as the testator. But in Article 832 of the Civil Code explains that if the heir is a Muslim, while the heirs are non-Muslims, then they are still entitled to inherit each other. ${ }^{24}$

In addition to these naqli reasons, aqli argument through the qiyas (analogy) method that the prohibition of damage due to religious differences does not include a prohibition for Muslims to inherit from their non-Muslim relatives. Therefore, if someone has a kitabiyah infidel wife who died, then her husband who is Muslim can receive inheritance rights. Especially in terms of damaging causes, including because of marital relations. So, because of the ability to get married with a Jewish or Christian woman, so should the case with inheritance.

This group limits the right of inheritance unilaterally, so that the arguments presented are still not much different from the views of the first group. The difference is casuistic and tends to bring discriminatory law. Therefore, the view of

\footnotetext{
${ }^{22}$ Abu Daud Sulaiman, Sunan Abu Daud, Juz III, p. 126.

${ }^{23}$ Marwan, Hadis Tentang Kedudukan Ahli Waris Beda Agama, p. 104.

${ }^{24}$ Khalid, "Pandangan Fuqaha Tetang Kewarisan Anak dari Hasil Perkawinan Beda Agama Menurut KUHP Perdata dan Kompilasi Hukum Islam." Al-Bayyinah 2.2 (2018): h. 97.
} 
the second group is refuted by the scholars, as quoted by Al-Nawawi that the scholars' argument is stronger and authentic. Muaz's argument is very weak, especially the hadith narrated from al-Daraquthni which is used as the basis is not right. The Hadith shows the primacy of Islam over other religions. The virtue in terms of religious status, there is no relationship with the problem of inheritance. Even Imam Nawawi himself regretted why it was not the Usamah hadith which was used as an excuse or the Muaz group did not know of this hadith. Including alBustani said that Muaz's view was rejected by the scientific community. ${ }^{25}$

Differences of opinion among Muslim scholars and jurists, especially those related to differences in interpretation of the traditions of Usamah which contain the inheritance doctrine of inheritance inherited by the cause of religious differences. Differences in approaches or benchmarks determine the value of differences in religious thought. Whatever form of application of Islamic law on inheritance among Muslims, the juridical aspects that are ijbari and Islamic personality still dominate the thought and practice of inheritance.

Efforts towards the contextuality of Islamic teachings, even though texts on the inheritance barrier can be understood in accordance with the absolute form of pronunciation but based on the thought of the concept of legal sources which are still zanni and muamalah, then there are opportunities to interpret the inheritance laws of different religions in a contextual way, both in the cultural context as well as the structure of Indonesian society so that Islamic inheritance law can accommodate plurality and change according to the evolving social and political context. Even dialectics are needed between the texts (The Holy Quran and Hadith) with the Indonesian ' urf (customs) that rely on maqashid al-shariah, namely the basic objectives of Islamic law that intend to achieve, guarantee and preserve the benefit of the ummah.

The question that arises is whether contemporary scholars are sufficient to accept the results of old ideas with all their arguments or have not had time to be appointed and do not need answers. If the first aspect is used as a measurement, it turns out that modern thought with a rational and contextual approach, on the one hand has the courage to try or can be said to have the courage of ijtihadi, but on the other hand still lacks the courage to try to interpret other parts of Islamic teachings. If the second reason is the answer, is it not yet time to try to rethink, at least it does not change and sue the text, as is the ethics and ijtihadi system that has been developed and practiced so far in other social problems. According to the author, one thing that is very urgent to be reinterpreted, at least to re-understand the

\footnotetext{
${ }^{25}$ Imam Abi Sulaiman Hammad bin Muhammad al-Khathabi al-Bustani, Ma'alim al-Sunnah
} Syarh Sunan Abu Daud, Vol. 4 (t.c ; Beirut: Dar al-Kutub al-Alamiyah,1991), p. 93. 
meaning contained in the Usamah hadith text. Therefore, contemporary scholars are still fixated on the classical figh doctrine with all its arguments. Religious reasons are still an apologetic basis for social relations between Muslims and nonmuslims.

Another question that needs to be raised is whether there is an alternative thought that can be an alternative solution to the problems faced by Muslims today and in the future with global trends and the need to rule out religious discriminatory thought in social relations based on the initial hypothesis that religion is no longer an excuse and an inappropriate to be a separator in a permanent relationship between fellow human beings.

The results of the formulation of Islamic inheritance law seminars organized by the Ministry of Religion of the Republic of Indonesia in Jakarta on May 22-26, 1978 and April 5-8, 1982. The results decided and gave a new paradigm for the development of contemporary Islamic legal thinking about inheritance, specifically the inheritance with different religions. In the fourth point, the results of the formulation are said 'Families or relatives who are prevented from becoming heirs due to religious differences can get some inheritance by will'. ${ }^{26}$

The preamble and recommendations of the results of this seminar show the development of thought among scholars. It was an effort to re-actualize and reinterpret the meaning of the teachings of Islam which are incompatible with maqashid al-sharia. Subhi Mahmasani firmly said that:

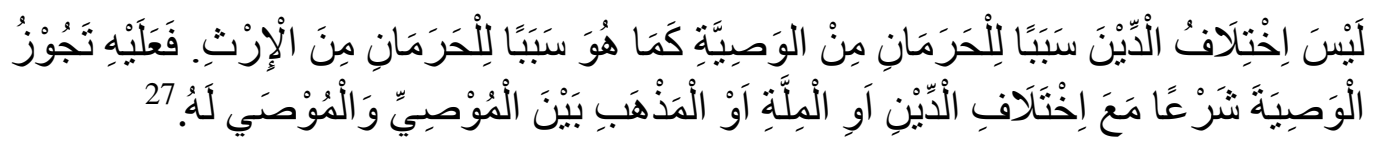

The meaning:

Religious differences are not the reason for being unclean in giving a will, as these religious differences are the reason for being prohibited in the process of inheritance. Therefore, in Sharia, a will is permitted even though the giver and recipient of a testament are of different religions, states, and schools of thought.

Masjfuk Zuhdi also agreed with Mahmasani, that through a will and grant can be used as an alternative to the inheritance with different religions. The argument that is found that the nature of faraid law is ijbari, meaning that it is a provision of Allah and His Messenger that is an obligation for every Muslim to obey it, but in practice it is possible for flexibility through peace between heirs.

\footnotetext{
${ }^{26}$ Kementerian Agama RI., Laporan Hasil Seminar Hukum Waris Islam (Jakarta: Dirbimbaperais, 2017), p. 3.

${ }^{27}$ Subhi Mahmasani, al-Mabadi al-Syari'ah wa al-Qanun fi al-Hijr wa al-Nafaqat wa al-Mawaris wa al-Washiah (4 ${ }^{\text {th }}$ Ed.; Beirut: Dar al-Ilmi li al-Malayin,1967), p. 181.
} 
Alternatives that can be taken are the will and grant system. The will system, a person makes a message orally or in writing before a witness that he gives something to an heir or not or to an agency or institution after he dies. Whereas through grants, a person while still living healthy, has distributed property to heirs, especially to members of the nuclear family (husband or wife and children) with the intention that the property falls to those who are desired for welfare and in the future after he died, there would be no dispute between the heirs. ${ }^{28}$

Mahmud Syaltut, one of the Muslim scholars from Egypt, once described the wisdom of distributing testaments to family members with the aim of drawing closer to one another's hearts, binding one another, one side paying attention to the other, if some were given or a certain class of experts only inheritance, their hearts will be far apart, the destruction of family relations, and even hostility tends to occur. Syaltut provided aqli arguments for the wisdom of division based on the concept of benefit, as the concept of al-tasyri wisdom is related to the permissibility of a Muslim male marriage with a woman expert on the book. According to him that the attitude of Islam towards other religions, which is intended through the bond of marriage with the aim that their children have an uncle from the book of experts and if there is a relationship between these uncles. Then it becomes strong ties and relations between the two people, including the exchange of food and drink cause closeness and connect love. ${ }^{29}$

As can be understood from contemporary Islamic thinkers through alternative channels. Basically, a will is allowed for those who do not get an inheritance because it is blocked because their inheritance is taken by heirs who are more entitled or hindered due to religious differences. According to them nonMuslim heirs can get part of the inheritance through the obligatory will. This opinion was expressed by bin Hazm, At-Tabari and Muhammad Rasyid Rida. Bin Hazm also expressed his opinion that a mandatory will is a will given to relatives who for some reason do not get part of the inheritance and are not given a will by someone who dies. While the deceased person has an inheritance for which an obligation to take will apply. ${ }^{30}$ According to the opinion of the author, heirs who have different religions from heirs, it is possible to get inheritance rights, both to obtain the right of muqaddarah or through alternative channels of the obligatory wills.

These various views of inheritance from different religions gave rise to two

${ }^{28}$ Masjfuk Zuhdi, Studi Islam III (2 ${ }^{\text {nd }}$ Ed.; Jakarta: Raja Grafindo Persada, 1993), p. 70-73

${ }^{29}$ Mahmud Syaltut, Islam Aqidah wa al-Syariah, translated by Bustani A. Gani which entaitled, Islam sebagai Aqidah dan Syari'ah, Vol. 3 (2 ${ }^{\text {nd }}$ Ed.; Jakarta: Bulan Bintang, 1980), p. 78.

${ }^{30}$ Fahmi Al Amruzi, Rekonstruksi Wasiat Wajibah dalam Kompilasi Hukum Islam (t.c ; Yogyakarta: Aswaja Pressindo, 2012), p. 22. 
poles of thought, namely classical thought which tends to be textualist, both in legal material and its application. Contemporary thinking that is alternative in nature, while still recognizing legal texts, but in practice it is possible to be contextualized. This last category is also called alternative thinking.

\section{CONCLUSION}

Contemporary figh studies conclude that religious differences are one of the causes of the inheritance process being obstructed. However, when the meaning of the hadith is abstracted in the context of the present and global trend by linking the basic principles throughout the provisions of Islamic law in the CLD-KHI with the concept of benefit (maqashid al-shariah). Religious discriminatory thinking in social relations needs to be set aside. It is based on the initial hypothesis that religion is no longer a reason or an inappropriate to be a separator in a permanent relationship between fellow human beings. As social beings, human beings in all aspects of life are not able to break away from its association with others. Then the heirs who are prevented from obtaining inheritance due to religious differences, still obtain a part of the inheritance from the inheritance through alternative channels in the form of mandatory wills.

Counter Legal Draft of Islamic Law Compilation (CLD-KHI) which is an antithesis to the Compilation of Islamic Law (KHI) which concludes that religious differences are not obstacles to the inheritance process. In reviewing legal epistemology, the basic principles that animate all the provisions of Islamic law in CLD-KHI both pluralism (ta'addudiyyah), nationality (muwathanah), human rights enforcement (iqamat al-huquq al-insaniyyah), democratic (dimuqrathiyyah), benefit (mashlahah), and gender equality (al-musawat al-jinsiyyah), it must still be a consideration for carrying out legal reform, in order to realize an Islamic inheritance law that does not contradict the texts in Islam as well as the objectives of the Sharia (maqashid al-shariah).

\section{REFERENCES}

Al- Qurtubi, Ibnu Rusyd. Bidayat al-Mujtahid wa nihayat al-Muqtasid, Juz V. $1^{\text {st }}$ Ed.; Beirut: Dar al-Kutub al-Ilmiyah, 1996.

Al-Amruzi, Fahmi. Rekonstruksi Wasiat Wajibah dalam Kompilasi Hukum Islam. t.c; Yogyakarta: Aswaja Pressindo, 2012.

Al-Asqalani, Ibnu Hajar. Fath al-Bari bi Syarh Shahih al-Bukhari, Juz XII. t.c; Beirut: Dar al-Fikr, 1993. 
Al-Bukhari Muhammad Ibnu Ismail. Sahih al-Bukhari, Juz IV. Indonesia: Maktabah Dahlan, t.th.

Al-Bustani, Imam Abi Sulaiman Hammad bin Muhammad al-Khathabi, Ma'alim alSunnah Syarh Sunan Abu Daud , 4 ${ }^{\text {th }}$ Ed.. t.c ; Beirut: Dar al-Kutub alAlamiyah, 1991.

Al-Zuhaili, Wahabah. Al-Fiqh al-Islami wa Adillatuh, Juz X. $4^{\text {th }}$ Ed.; Damsyik: Dar alFikr, 1997.

Cawidu, Harifuddin. Konsep Kufr dalam The Holy Quran; Suatu Kajian Teologi dengan Pendekatan Tafsir Tematis. $4^{\text {th }}$ Ed.; Jakarta: Bulan Bintang, 1991.

Kementerian Agama RI. The Holy Quran dan Terjemahnya. t.c; Jakarta: PT. Intermasa, 2017.

Khalid, K. (2018). PANDANGAN FUQAHA TETANG KEWARISAN ANAK DARI HASIL PERKAWINAN BEDA AGAMA MENURUT KUHP PERDATA DAN KOMPILASI HUKUM ISLAM. Al-Bayyinah, 2(2), 81 100.

Khallaf, Abdul Wahab. Ilmu Ushul Fiqh, diterjemahkan Noer Iskandar al-Barsany dan Moh. Tolchah Mansoer, Kaidah-Kaidah Hukum Islam. $4^{\text {th }}$ Ed.; Jakarta: Raja Grafndo Persada, 1994.

Mahmasani, Subhi. al-Mabadi al-Syari'ah wa al-Qanun fi al-Hijr wa al-Nafaqat wa alMawaris wa al-Washiah. $4^{\text {th }}$ Ed.; Beirut: Dar al-Ilmi li al-Malayin,1967.

Marwan. Hadis Tentang Kedudukan Ahli Waris Beda Agama. Karya Ilmiah, 2001.

Sulaiman, Abu Daud. Sunan Abu Daud, Juz III. t.c; Darul Hadis: Maktab Dahlan, 1988.

Syafi'ie, M. Hak Non Muslim terhadap Harta Waris. t.c; Yogyakarta: Al- Mawarid, 2011.

Syaltut, Mahmud. Islam Aqidah wa al-Shariah, translated by Bustani A. Gani which entitled, Islam sebagai Aqidah dan Syari ${ }^{\circ}$ h, Vol. 3, 2 ${ }^{\text {nd }}$ Ed.; Jakarta: Bulan Bintang, 1980.

Umar, Mustafa. Konsep Kufur dalam The Holy Quran dan Proyeksinya Terhadap Teks Hadis, t.c; Makassar: Al- Risalah, 2012.

Wahid, Abdurrahman. Hukum Islam di Indonesia. $2^{\text {nd }}$ Ed.; Bandung: Remaja Rosdakarya, 1994.

Zuhdi, Masjfuk. Studi Islam III. 2 ${ }^{\text {nd }}$ Ed.; Jakarta: Raja Grafindo Persada, 1993. 